\title{
Light-induced synthesis of micron-sized metallic silver in aqueous extract of Rivina humilis L. fruits and its interaction with Corptotermes curvignathus
}

\author{
Salprima Yudha S., ${ }^{1, *}$ Aswin Falahudin', Morina Adfa' ${ }^{1}$ Irfan Gustian', Herlina ${ }^{1,2}$ \\ 'Department of Chemistry, Faculty of Mathematics and Natural Sciences, Universitas Bengkulu \\ Jalan W.R, Supratman, Kandang Limun, Kota Bengkulu, Indonesia \\ ${ }^{2}$ Akademi Farmasi Al-Fatah, Jalan Indragiri Gang 3 Serangkai, Padang Harapan, \\ Kota Bengkulu, Indonesia
}

*Corresponding author email: salprima@unib.ac.id; sp.yudha.s@gmail.com

Received December 06, 2020; Accepted May 31, 2021; Available online July 20, 2021

\begin{abstract}
The aqueous extract of Rivina humilis was suitable to reduce silver ions $\left(\mathrm{Ag}^{+}\right)$to form micron-sized metallic silver at room temperature and without any addition of external reducing agent or stabilizer compounds. The reduction process was assisted by light, indicated by the colour change of the reaction mixture and supported by the appearance of peak at $455 \mathrm{~nm}$ in spectrophotometric analysis when the reaction was carried out under room light. Based on transmission electron microscopy (TEM) analysis, the as-prepared metallic silver was in spherical form. The analysis results using particles size analyzer (PSA) show their particles distribution from micro to nano size (average size was $199 \mathrm{~nm}$ ). The interaction behaviour of micron-sized metallic silver/extract solution with Corptotermes curvignathus termites shows that the silver gives small additional effects along with the activity of the extract.
\end{abstract}

Keywords: Rivina humilis; metallic silver; Corptotermes curvignathus; Light-Induced synthesis

\section{INTRODUCTION}

The design and production of nanometals with specific applications can be achieved by controlling their shape or size [Khan, Saeed \& Khan, 2019] and particles alignment [Astuti, Poolton, Butenko, \& Šiller, 2014]. To this aim, green nanotechnology has emerged as a powerful tool (Polshettiwar \& Varma, 2010). Green nanotechnology for the synthesis of metal nanoparticles involves marine organisms, fungi, bacteria, and plants as media as well as reaction agents. Some reviews on the green synthesis and applications of nanoparticles of silver (AgNPs)and other metals have appeared in recent years (Beyene, Werkneh, Bezabh, \& Ambaye, 2017; Rafique, Sadaf, Rafique, \& Tahir, 2017; Sood, \& Chopra, 2018). Metallic silver having nano- and microsizes is one of the most important nanomaterials (Siddiqi, Husen, \& Rao, 2018), and a number of synthetic methods have been developed to obtain silver nanoparticles with appropriate sizes and shapes for specific applications (Singhal, Singha, Bhattacharya, \& Gupta, 2017; Li, Xu, Li, Xhao, \& Chen, 2018; Oza et al., 2020).

Biosynthesized nanoparticles have been used as catalysts, antifungal and antibacterial agents, and heavy metal sensors. A few studies have shown that biogenic synthesized AgNPs exhibit activity against some types of termites. For instance, AgNPs synthesized by Daphne mucronata leaves extract are more effective against Heterotermes indicola termite than the corresponding leaves extract (Shah, Lutfullah, Ahmad, Khalil, \& Maaza, 2018). In addition, Zizyphus jujuba extract-mediated synthesis led to AgNPs that can effectively control the Centrocestus formosanus termite population (Jayamala, Murugan, Maheswari, \& Singh, 2018). It is noteworthy that, although silver is an important additive in the field of paints and preservatives, it is not effective as anti termite agent in many cases (Green III, \& Arango, 2007). Other metallic compounds have been also tested as wood preservatives against termite attack. For example, zinc oxide nanoparticles could also inhibit the eastern subterranean termites (Reticulitermes flavipes) population growth by slowacting, non-repellent stomach poisoning (Clausen, Kartal, Arango, \& Green III, 2011).

Aqueous extracts of $R$. humilis fruits have been tested for hematological parameters in rats. The results showed that the extract did not affect the hematological profile of rats even after daily administration for 35 days (Khan, Joseph, Muralidhara, Ramesh, Giridhar, \& Ravishankar, 2011). Moreover, R. humilis berry extract, rich in betalains, was proved to be suitable as food colorant. The color of food was stable under thermal treatment and storage at $5{ }^{\circ} \mathrm{C}$ for 6 months (Khan et al., 2015). 
The same extract had been previously reported to have bioactivity and citotoxicity toward cancer cells (Khan, Harsha, Giridhar, \& Ravishankar, 2012) and as natural anti-feedant, oviposition deterrent, and ovicidal and larvicidal agent against field pest Spodoptera litura (Arumugam et al., 2015). Betanin, a betalain pigment, has been isolated from red beet roots. An interaction between the isolated betanin with $\mathrm{Ni}^{2+}$ and $\mathrm{Cu}^{2+}$ ions was suggested on the basis of a peak that appeared at 505-525 nm in the UVvis spectrum depending on the $\mathrm{pH}$ solution. On the other hand, no peak was detected upon mixing the betanin solution with $\mathrm{Ag}^{+}$ions (Wybraniec et al., 2013).

Apart from this report, no other study on any specific interaction between betanin and related compounds from $R$. humilis fruits extract with metal ions has been published, although these fruits have been claimed to contain betalains and their derivatives. Herein, we describe the study of the interaction of aqueous extract of $R$. humilis fruits with $\mathrm{Ag}^{+}$ions, especially in the form of $\mathrm{AgNO}_{3}$ salt. One of the main findings in this research is the role of light in accelerating the interaction between the active compounds in aqueous extract of $R$. humilis fruits with silver ions. It is known that in some cases the interaction of one compound with another compound needs external assistance such as temperature, light irradiation, electromagnetic waves, electric-field and several other physical factors. In addition to the fundamental study of the role of light in this reaction, the activity of the resulting metallic silver particles against termites was also evaluated.

\section{EXPERIMENTAL SECTION}

\section{Chemicals and Fruit Samples}

All chemicals used were of analytical grade. Silver nitrate was purchased from Merck. The glassware used in these experiments was washed using aqua regia prior to use. All solutions were prepared using demineralized water. Fresh fruits of $R$. humilis L. were collected from Bengkulu city, Indonesia.

\section{Green-Synthesis of Metallic Silver Particles}

The R. humilis fruits (Figure 1a) were collected freshly from Bengkulu city area and washed using aquadest. For the preparation of $R$. humilis fruits extract, one gram of dust-free fruit was put in an Erlenmeyer, followed by addition of $100 \mathrm{~mL}$ of demineralized water. The mixture was heated and stirred using a hotplate-magnetic stirrer at $70{ }^{\circ} \mathrm{C}$ for $30 \mathrm{~min}$, and subsequently cooled to room temperature. The mixture was filtered using Whatman paper filter No. 3. The obtained fresh solution was transferred to a sample bottle, followed by addition of silver nitrate solution $\left(1 \times 10^{-2} \mathrm{M}\right)$ under stirring at room temperature under two reaction conditions i.e., under light irradiation and in dark condition. Additional stirring was carried out for $2 \mathrm{~h}$, and the sample was then kept at the same temperature for 24 $\mathrm{h}$ without stirring.

\section{Characterization of Green-Synthesized Metallic Silver Particles}

Visual observation of the reaction mixture was performed using a portable camera and a UV-vis spectrophotometer (Agilent 60) at the scanning range of $380-800 \mathrm{~nm}$. The solution is diluting from the main solution by picked up $0.2 \mathrm{~mL}$ of the reaction mixture and diluted to $5.0 \mathrm{~mL}$ total solution using demineralized water. A particle size analyzer (PSA)

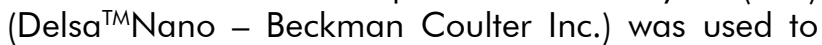
determine the size distribution of the silver particles in the reaction mixture. The reaction mixture (in demineralised waster) was used directly for PSA analysis. The observation of particles shape was carried using Transmission Electron Microscope (TEM) (JEOL JEM 1400).

\section{Termite Collection}

The tested termite species, C. curvignathus, was collected together with nest wood from the Kandang Limun campus of Universitas Bengkulu. The collected termites were kept in plastic trays and reared in the laboratory in dark condition at room temperature.

\section{Interaction Behaviour Test of Green-Synthesized Metallic Silver with C. curvignathus}

The no-choice bioassay method of (Kang, Matsushima, Sameshima, \& Takamura, 1990) was employed with slight modifications to evaluate the antitermitic activity of five solutions: demineralized water, $\mathrm{AgNO}_{3}$ solution, $\mathrm{R}$. humilis extract, micronsized metallic silver/extract solution, and 10 times diluted of micron-sized metallic silver/extract solution to study the behaviour of silver particles toward $C$. curvignathus termites. The 10 times diluted of micron-sized metallic silver/extract solution was prepared by diluting the as-prepared reaction mixture 10 times with demineralized water. A piece of filter paper (Whatman no. 3 and $2 \mathrm{~cm}$ in diameter) treated with the reaction mixture of $R$. humilis extract$\mathrm{AgNO}_{3}$ was used for the main experiment. After the solvent (demineralized water) was removed from the treated filter papers by air-drying at $27 \pm 2{ }^{\circ} \mathrm{C}$, active termites (20 workers and 2 soldiers) were put on the filter papers and kept in Petri dishes $190 \mathrm{~mm}$ diameter). The covered dishes were then placed in a dark room at room temperature for four days. A few drops of water were periodically dripped onto the bottom edge of each Petri dish. The same procedure was followed for the rest of the solutions, and the demineralised water was used as a control. Termite mortality was calculated on the basis of visual inspection.

\section{RESULTS AND DISCUSSION}

Synthesis results and characterization of metallic silver

Extraction of the essential compounds from R.humilis fruits (Figure 1a) was achieved by dissolution in demineralised water at $70^{\circ} \mathrm{C}$ for short periods of time. The extraction process of $R$. humilis 
fruits was monitored by the color change of the solution from transparent to red (Figure 1b). The $R$. humilis fruits extract (Figure 1c) was obtained by filtration and used freshly to synthesize the metallic silver particles (Figure 1c to $1 \mathrm{~d}$ ).

When the reduction of silver ions to metallic silver was carried out under light irradiation for $24 \mathrm{~h}$, the reaction proceeded smoothly at room temperature (Figure 2, left), whereas no colour change was observed in the absence of light irradiation (Figure 2, right). In addition, in the present condition, the use of $9 \mathrm{~mL}$ of fruits extract versus $1 \mathrm{~mL}$ of $\mathrm{AgNO}_{3}$ solution gave significant colour change.

These results suggests that the presence of some active compounds in the $R$. humilis extract was not enough to reduce the silver ions to metallic silver; conversely, this process occurred in the presence of light due presumably to direct activation of either the silver ions or the compounds in the extracts. This might occur because of the synergistic performance from several compounds in the aqueous extract of $R$. humilis fruits. However, the reaction was very slow (24 hours) even though it was assisted by light. The colour change of the reaction mixture was considered the first signal of the reaction progress (Shah, Lutfullah, Ahmad, Khalil, \& Maaza, 2018). This phenomenon also indicates that the presence of excess extract (capping agent) is needed to reduce the silver ions and stabilize the particles from aggregation processes (El-Nour, Eftaiha, Al-Warthan, \& Ammar, 2010; Seifipour, Nozari, \& Pishkar, 2020; Mikhailova, 2020). Although the mechanism of the reduction of silver ions induced by light remains uncertain, one possibility is that the reduction reaction proceeds via mechanisms proposed for photo-catalytic reduction of silver ions in the presence of citrates anions (Maillard, Huang, \& Brus, 2003; Redmond, Wu, \& Brus, 2007) or other compounds that available in $R$. humilis extract and supported by the electron transfer from the compounds to the silver ions as acceptor (Kumar, Singh, Mohan, \& Hasan, 2016; Fierascu, et al, 2017); Rahman, et al, 2019).

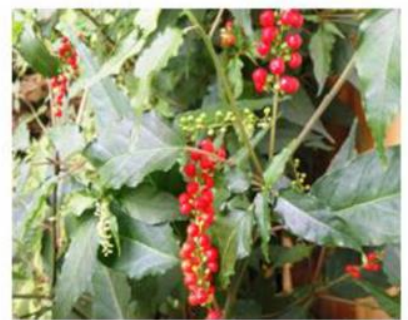

(a)

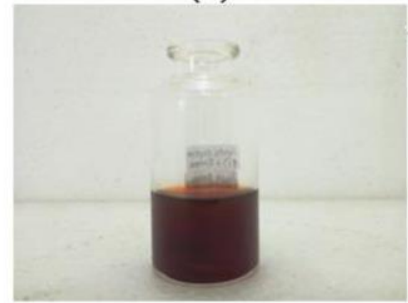

(d)

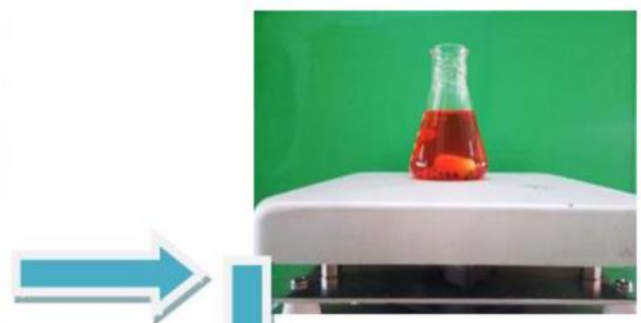

(b)

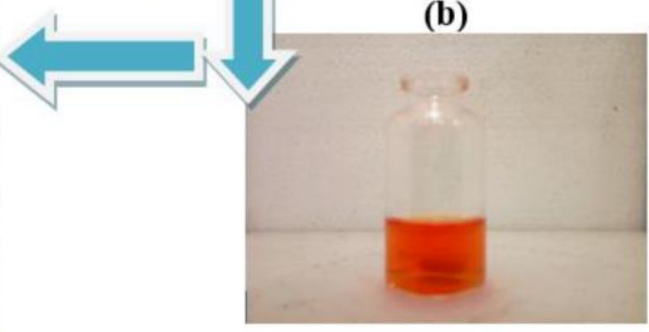

(c)

Figure 1. (a) R. humilis L. plant and their fruits, (b) extraction process, (c) clean extract after filtration, and (d) reaction mixture of $\mathrm{AgNO}_{3}$ and the extract

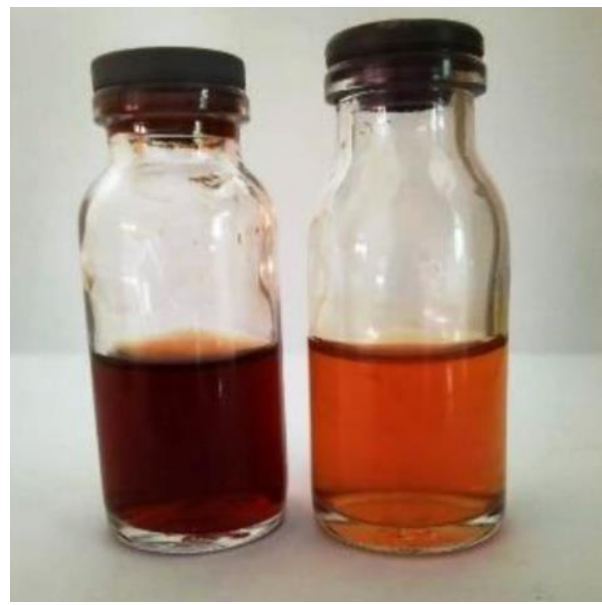

Figure 2. (Left) Reaction mixture under room light irradiation; (Right) reaction mixture in dark condition 


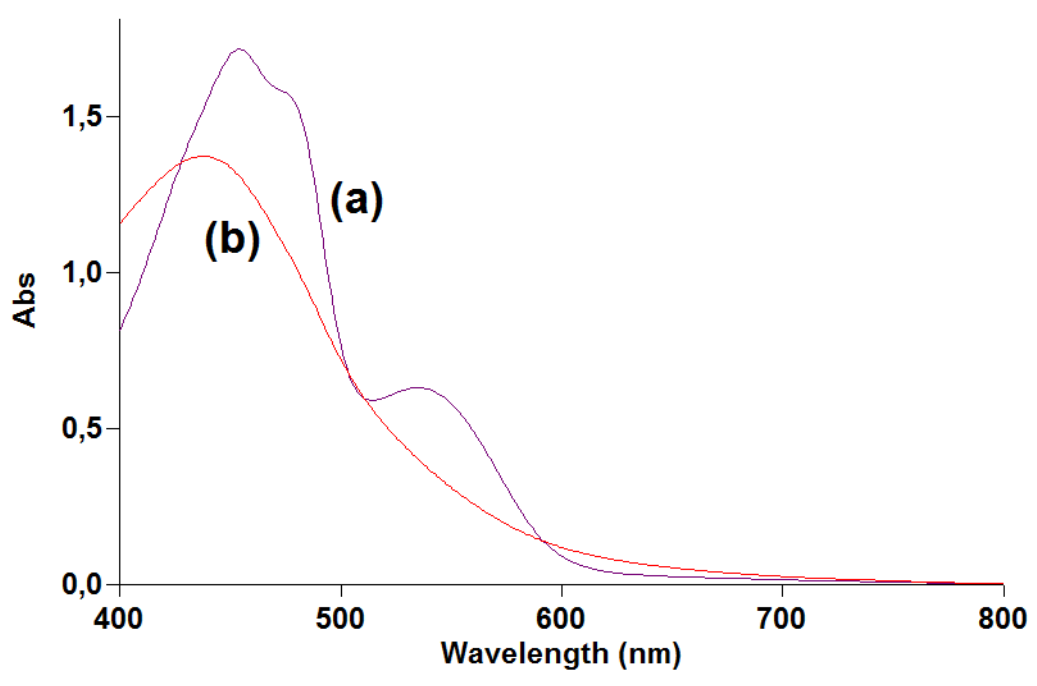

Figure 3. Spectrophotometry analysis results of (a) $R$. humilis leaves extract and (b) reaction mixture of the extract-AgNO3

Further characterization was performed using a UV-vis spectrophotometer as illustrated in Figure 3. The aqueous extract gave rise to specific peaks at 465 and $550 \mathrm{~nm}$, which were almost coincident with those of previously reported results at $\mathrm{pH} 5$ (Khan, et al., 2012). In addition, the reaction mixture of fruits extract- $\mathrm{AgNO}_{3}$ yielded a new peak at $\lambda=455 \mathrm{~nm}$.

The results of our research demonstrate that aqueous extracts of $R$. humilis fruits could be used as media for the synthesis of silver micro-and nanoparticles in the presence of light. The formation of silver particles was evidenced by the appearance of a new peak at $455 \mathrm{~nm}$ in the UV-vis spectrum (Figure 3), which is in coincident with the specific surface plasmon resonance (SPR) of metallic silver nano-and microparticles (Mlalila, Swai, Hilonga, \&
Kadam, 2017). In addition, compounds peaks as shown in aqueous extract of $R$. humilis fruits (Figure $3 a)$ have disappeared when the solution was reacted with silver ions in the presence of light (Figure 3b). Although the exact reaction mechanism are still not fully understood, seems to have been caused by an oxidation process of the corresponding active compounds as a couple of redox reactions in order to reduce silver ions [Azis et al., 2019] or by formation of coordination complexes [Nguyen, Vo, Le, Thi, \& Thi, 2020] and/or followed by decomposition of some essential organic compounds in the reaction mixture. Further investigation using TEM revealed that the current metallic silver in aqueous extract of $R$. humilis was in spherical form (Figure 4).
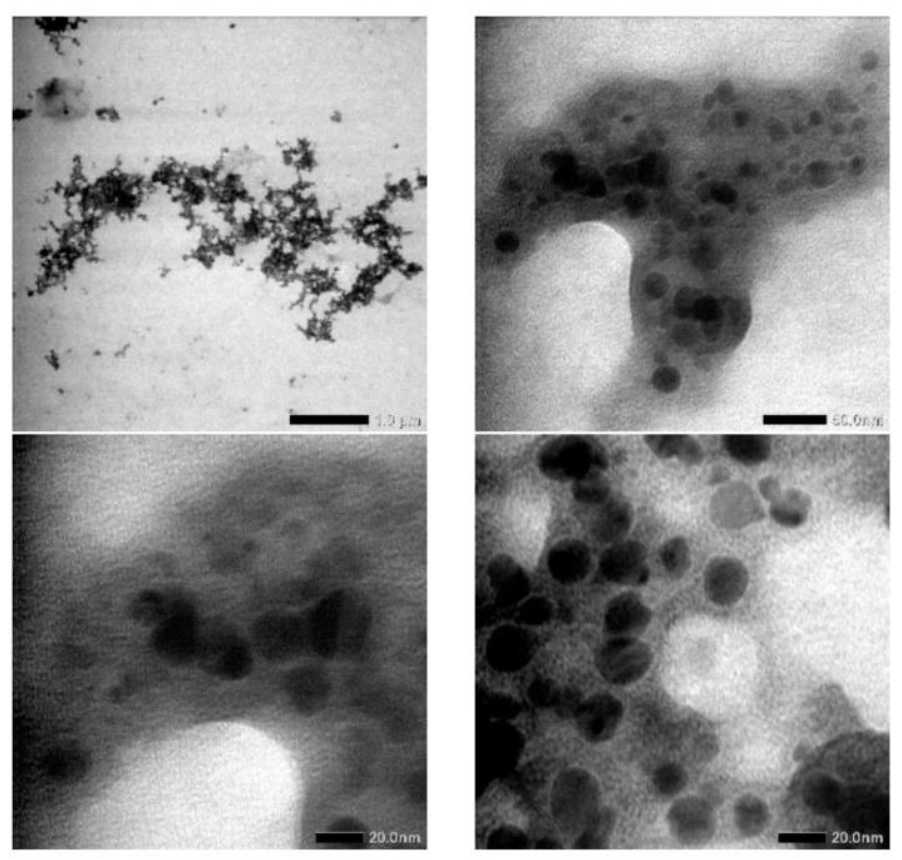

Figure 4. Morphology pattern of metallic silver using TEM 


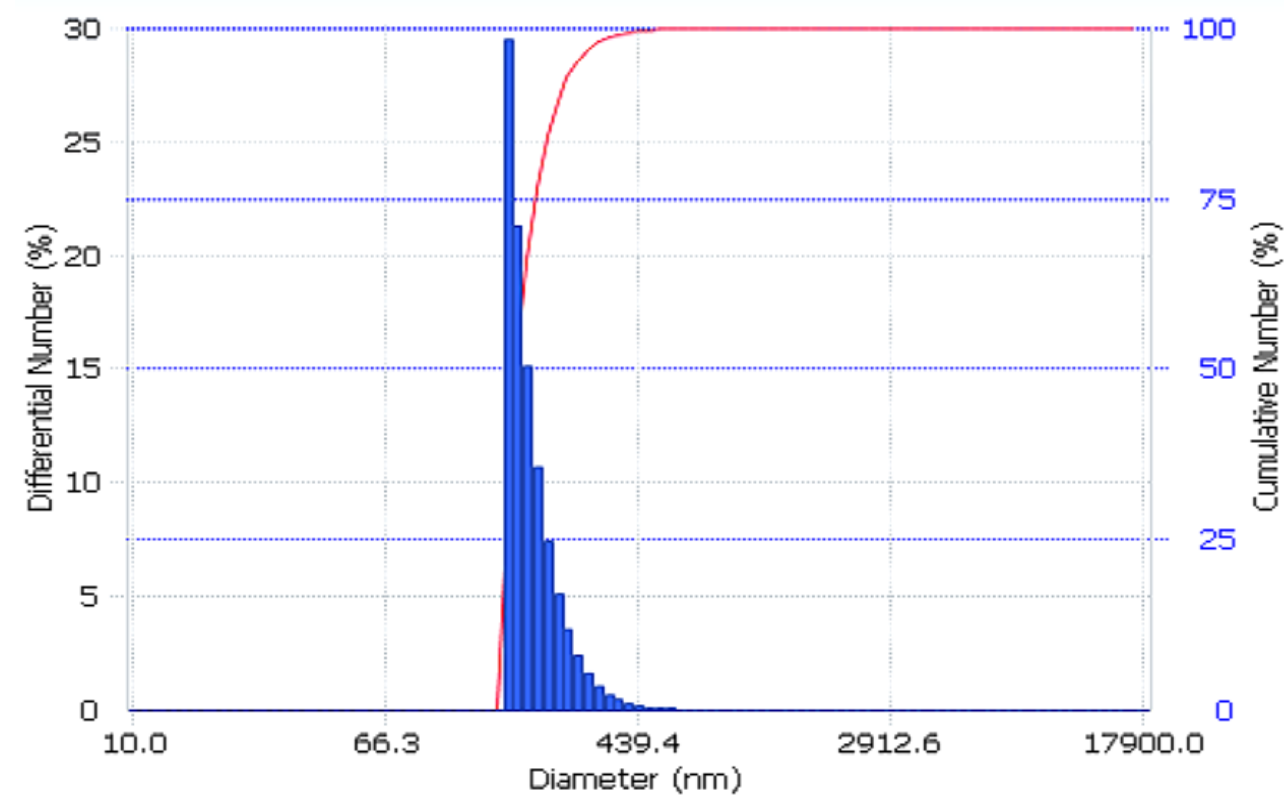

Figure 5. Particles size distribution pattern using a particles size analyzer (PSA)

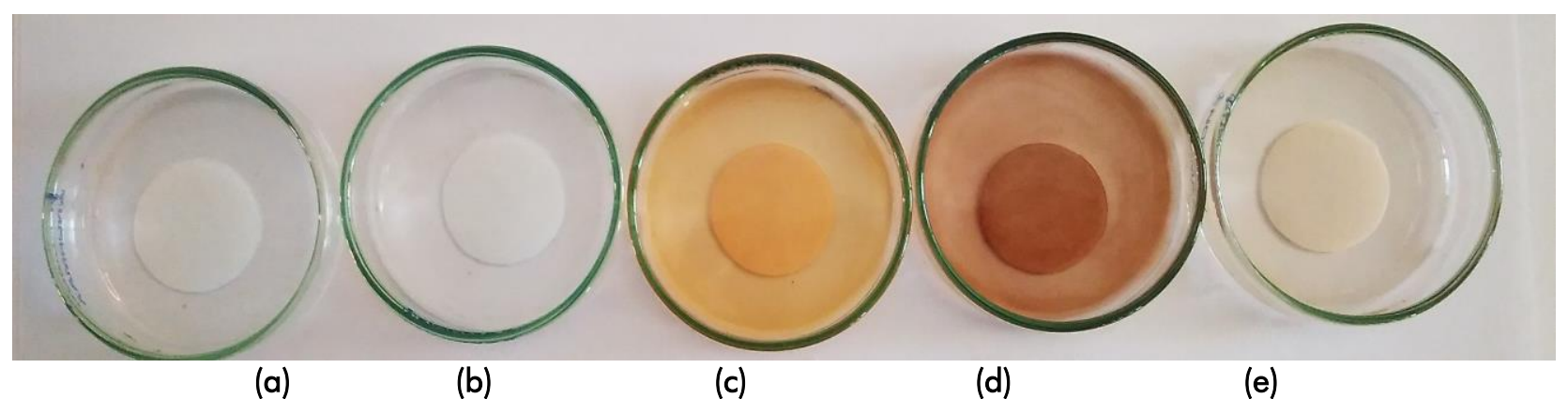

Figure 6. Immersion of Whatman filter paper in (a) demineralized water, (b) $\mathrm{AgNO}_{3}$ solution, (c) R. humilis extract, (d) micron-sized metallic silver/extract solution, and (e) 10 times diluted of $6 \mathrm{~d}$

Furthermore, the average size of the particles in the reaction mixture was determined to be $199 \mathrm{~nm}$ by using a PSA (Figure 5). This large size is probably due to instability of the capping agent in the extract. The polydispersity index (PDI) is 0,346 , which mean that the as-prepared sample is in a mid-range value of dispersity. It is known that some natural or synthetic organic compounds could play a significant role in the modification of the chemical characteristics of produced nanoparticles (Firdhouse, \& Lalitha, 2015).

\section{Interaction performance of green-synthesized metallic silver with $C$. curvignathus termites}

To evaluate the effect of the solutions on the termites, a Whatman filter paper (No. 1) was immersed in different solutions (demineralized water, $\mathrm{AgNO}_{3}$ solution, $R$. humilis extract, micron-sized metallic silver/extract solution, and 10 times diluted of micron-sized metallic silver/extract solution) as shown in Figure 6.
The behaviour of the silver particles toward termites was studied by using the reaction mixture as medium as well as filler for filter paper (Figure 6d e), which was used as food source for the termites. It's common to use the filter paper as food source in the corresponding experiment (Cornelius, \& Lax, 2005). To provide comprehensive results, silver nitrate and fruits extract solutions were used (Figure $6 b$ - c) as comparative samples. In addition, demineralised water was used as negative control (Figure 6a). The interaction assay of test samples were performed against $C$. curvignathus termites and the termite mortality was evaluated on a daily basis by visual inspection of 20 workers and 2 soldiers in a Petri dish containing the treated filter paper (Figure 7 as a representative). When termites encountered the disk, they immediately spread and a few of them clustered on top of the paper. The average amount of death termites (from two replicate experiments) are summarized in Figure 8. 


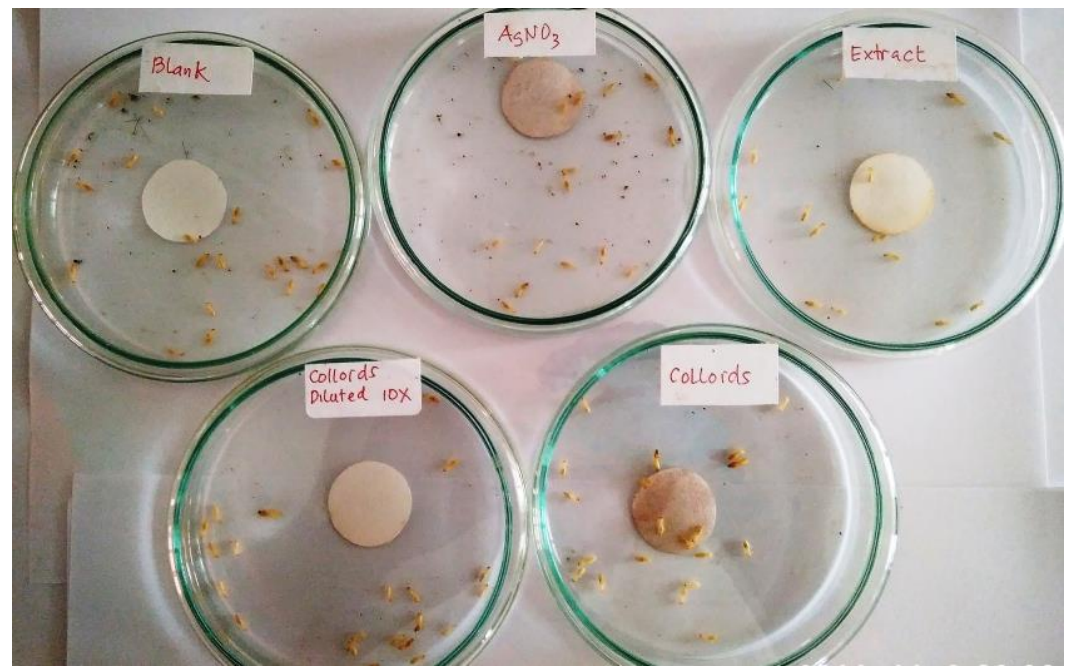

Figure 7. Antitermites test using no-choice method

$A=$ Soldier termites; $B=$ Worker termites

B

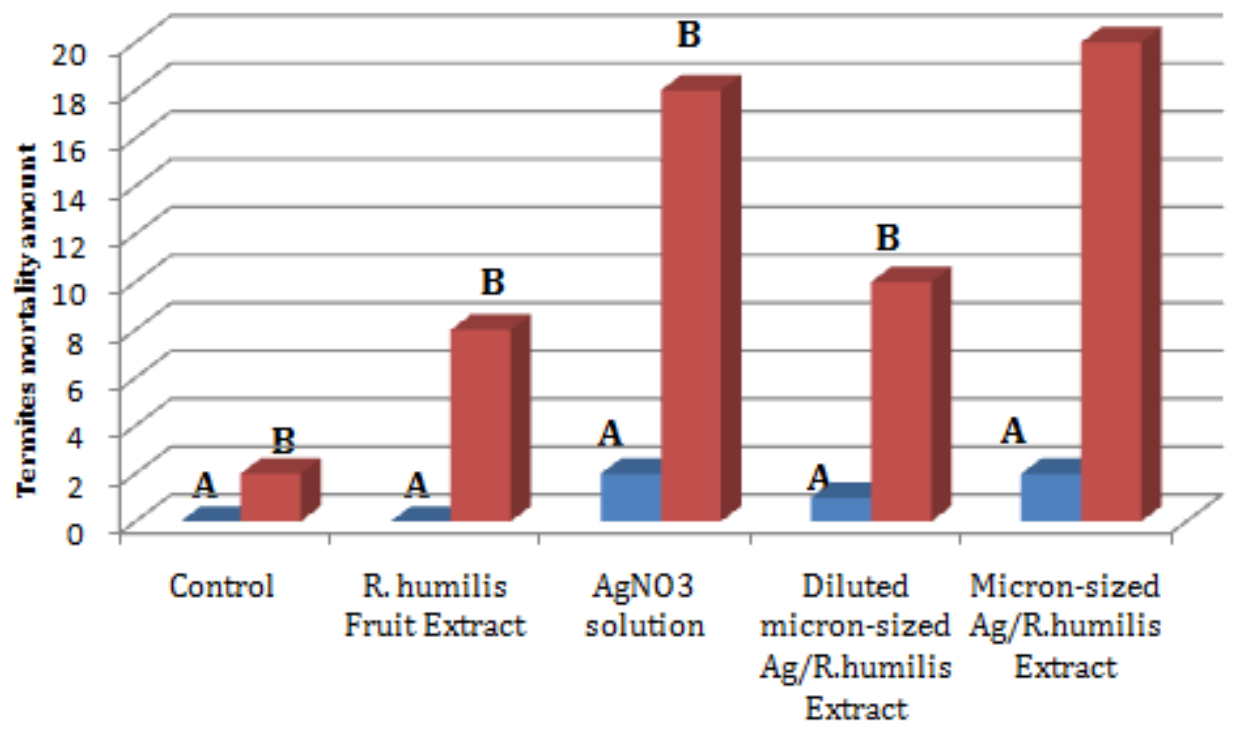

Figure 8. Average termite mortality using no-choice method with different types of treated paper as food source (after 4 days)

The results of direct investigation indicate that significant effects could be observed after the second day. Micron-sized metallic silver/extract solution caused $25 \%$ mortality of worker termites, whereas diluted micron-sized metallic silver/extract solution, silver nitrate solution, and the fruits extract caused only $10 \%, 15 \%$, and $20 \%$ mortality, respectively. These results clearly showed that the mortality of the workers termites caused by synergistic activity of the fruits extract and the silver particles. As expected, the control sample did not give any effect. The mortality might be due to the fast penetration of the materials into the termite cell causing slow-acting and stomach poisoning. After the third and fourth day of test, the mortality seemed to be uncontrolled due to an unsuitable living environment for the termites (Figure 8); therefore, no significance differences between the five samples evaluated could be extracted.

\section{CONCLUSIONS}

This is an inexpensive approach for the synthesis of silver micro-and nanoparticles using aqueous fruits extract of $R$. humilis $L$. The present environmentally friendly synthesis of inorganic materials showed that $R$. humilis could be used as an effective reducing agent in the presence of light irradiation for the synthesis of metallic silver particles at room temperature. Furthermore, the fruits extract and the corresponding micron-sized metallic silver particles were proved to be potentially applicable to control the population of $C$. curvignathus. 


\section{ACKNOWLEDGEMENTS}

The authors are indebted to the valuable support of Direktorat Riset dan Pengabdian Masyarakat (DRPM), Kementerian Riset, Teknologi, dan Pendidikan Tinggi, Republik Indonesia, via Hibah Penelitian Tim Pascasarjana 2018.

\section{AUTHOR CONTRIBUTIONS}

S.Y.S and IG designed the experiments and prepared the manuscript. MA supervised the works especially on the interaction of micron-sized metallic silver with termites. AF drew all the graphics and $\mathrm{H}$ participated in the characterization analysis. All authors read and approved the final manuscript.

\section{COMPLIANCE WITH ETHICAL STANDARDS}

The authors whose names are listed in the authorship do not have conflict of interest

\section{REFERENCES}

Arumugam, E., Muthusamy, B., Dhamodaran, K., Thangarasu, M., Kaliyamoorthy, K., \& Kuppusamy, E. (2015). Pesticidal activity of Rivina humilis L. (Phyłolaccaceae) against important agricultural polyphagous field pest, Spodoptera litura (Fab.) (Lepidoptera: Noctuidae). Journal of Coastal Life Medicine, 3(5), 389-394. DOI: 10.12980/JCLM.2.2014JCLM-2014-0059

Astuti, Y., Poolton, N.R.J., Butenko, Y.V., \& Šiller, L. (2014). Evaporation and alignment of 1 undecene functionalised nanodiamonds. Journal of Luminescence, 156, 41-48. DOI: http://dx.doi.org/10.1016/j.jlumin.2014.06.045

Aziz, S.B., Hussein, G., Brza, M.A., Mohammed, S.J., Abdulwahid, R.T., Saeed, S.R., \& Hassanzadeh, A. (2019). Fabrication of interconnected plasmonic spherical silver nanoparticles with enhanced localized surface plasmon resonance (LSPR) peaks using quince leaf extract solution. Nanomaterials, 9(11), 1557.

https://doi.org/10.3390/nano9111557

Beyene, H.D., Werkneh, A.A., Bezabh, H.K., \& Ambaye, T.G. (2017). Synthesis paradigm and applications of silver nanoparticles (AgNPs): a review. Sustainable Materials and Technology, 13, 18-23. DOI: https://doi.org/10.1016/ i.susmat.2017.08.001.

Clausen, C.A., Kartal, S.N., Arango, R.A., \& Green III, F. (2011). The role of particle size of particulate nano-zinc oxide wood preservatives on termite mortality and leach resistance. Nanoscale Research Letters, 6, 427. DOI: https://doi.org/10.1 186/1556-276X-6-427

Cornelius, M.L., \& Lax, A.R. (2005). Effect of summon preferred food source on feeding, tunneling, and bait station discovery by the Formosan subterranean termite (Isoptera:
Rhinotermitidae). Journal of Economic Entomology, 98, 502-508. DOI: https://doi.org/10.1093/jee/98.2.502

El-Nour, K.M.M.A., Eftaiha, A., Al-Warthan, A., \& Ammar, R.A.A. (2010). Synthesis and applications of silver nanoparticles. Arabian Journal of Chemistry, 3(3), 135-140. https://doi.org/10.1016/i.arabjc.2010.04.008

Fierascu, R.C., Fierascu, I., Lungulescu, E.M., Nicula, N., Somoghi, R., Diţu, L.M., Ungureanu, C., Sutan, A.N., Drăghiceanu, O.A., Paunescu, A., \& Soare, L.C. (2017). Phytosynthesis and radiation-assisted methods for obtaining metal nanoparticles. Journal of Materials Science, 55, 1915-1932 DOI: https://doi.org/10.1007/s10853-019-03713-3

Firdhouse, M.J., \& Lalitha, P. (2015). Biosynthesis of Silver Nanoparticles and Its Applications. Journal of Nanotechnology, ID829526, 18 pages http://dx.doi.org/10.1155/2015/829526

Green III, F., \& Arango, R.A. (2007). Wood protection by commercial silver formulations against eastern subterranean termites. The 38th Annual Meeting Jackson Lake Lodge, Wyoming, USA 20-24 May 2007, 1-6.

Jayamala, M., Murugan, A., Maheswari, S.U., \& Singh, A.J.A.R. (2018). Agro waste of Zizyphus jujuba extract-mediated synthesis of silver nanoparticles and its antitermite activity. European Journal of Biomedicals and Pharmaceutical Sciences, 5(7), 443-449..

Kang, H.Y., Matsushima, N., Sameshima, K., \& Takamura, N. (1990). Termite resistance tests of hardwoods of Kochi growth: the strong termiticidal activity kagonoki (Litsea coreana Leveille). Mokuzai Gakkaishi, 36(1), 78-84.

Khan, M.I., Joseph, K.M.D., Muralidhara, Ramesh H.P, Giridhar, P., \& Ravishankar, G.A. (2011). Acute, subacute and subchronic safety assessment of betalains rich Rivina humilis L. berry juice in rats. Food and Chemical Toxicology, 49(12), 3154-3157. DOI: https://doi.org/10.1016/j.fct.2011.08.022

Khan, M.I, Harsha, P.S.C.S, Giridhar, P., \& Ravishankar, G.A. (2012). Pigment identification, nutritional composition, bioactivity, and in vitro cancer cell cytotoxicity of Rivina humilis L. berries, potential source of betalains. LWT, 47(2), 315-323. DOI: https://doi.org/10.1016/j.Iwt.2012.01.025

Khan, M.I., Harsha, P.S.C.S., Chauhan, A.S., Vijayendra, S.V.N., Asha, M.R., \& Giridhar, P. (2015). Betalains rich Rivina humilis L. berry extract as natural colorant in product (fruit spread and RTS beverage) development. Journal of Food Science and Technologymysore, 52(3), 1808-1813. DOI: https://doi.org/10.1007/s13197-013-1175-8 
Khan, I., Saeed, K. \& Khan, I. (2019) Nanoparticles: Properties, applications and toxicities. Arabian Journal of Chemistry, 12, 908-931. DOI: http://dx.doi.org/10.1016/j.arabjc.2017.05.011

Kumar, V., Singh, D.K., Mohan, S., \& Hasan, S.H. (2016). Photo-induced biosynthesis of silver nanoparticles using aqueous extract of Erigeron bonariensis and its catalytic activity against acridine orange. Journal of Photochemistry and Photobiology B: Biology, 155, 39-50. DOI: https://doi.org/10.1016/ i.jphotobiol.2015.12.011

Li, W, Xu, X., Li, W., Xhao, Y., \& Chen, M. (2018). Green synthesis of micron-sized silver flakes and their application in conductive ink. Journal of Materials Science, 53, 6424-6432 DOI: https://doi.org/10.1007/s10853-017-1962-0

Maillard, M., Huang, P., \& Brus, L. (2003). Silver nanodisk growth by surface plasmon enhanced photoreduction of adsorbed $\left[\mathrm{Ag}^{+}\right]$. Nano Letters, 3(11), 1611-1615. DOI: https://doi.org/10.1021/nl034666d

Mikhailova, E.O. (2020). Silver nanoparticles: mechanism of action and probable bioapplication. Journal of Functional Biomaterials, 11(4), 84. DOI: https://doi.org/10.3390/ ifb 11040084

Mlalila, N.G., Swai, H.S., Hilonga, A., \& Kadam, D.M. (2017). Antimicrobial dependence of silver nanoparticles on surface plasmon resonance bands against Escherichia coli. Nanotechnology, Science and Applications, 10, 1-9. DOI: https://doi.org/10.2147/NSA. $\mathrm{S} 123681$

Nguyen, D.H., Vo, T.N.N., Le, N.T.T., Thi, D.P.N. \& Thi, T.T.H. (2020). Evaluation of saponinrich/poor leaf extract-mediated silver nanoparticles and their antifungal capacity. Green Processing and Synthesis, 9, 429-439. DOI: https://doi.org/10.1515/gps-2020-0044

Oza, G., Reyes-Calderón, A., Mewada, A., Arriaga, L.G., Cabrera, G.B., Luna, D.E., lqbal, H.M.N, Sharon, M., \& Sharma, A. (2020). Plant-based metal and metal alloy nanoparticle synthesis: a comprehensive mechanistic approach. Journal of Materials Science, 55, 1309-1330 DOI: https://doi.org/10.1007/s10853-019-04121-3

Polshettiwar V., \& Varma R.S., (2010) Green chemistry by nano-catalysis. Green Chemistry, 12, 743-754. DOI: https://doi.org/ $10.1039 /$ b921171c

Rafique, M., Sadaf, I., Rafique ,M.S., \& Tahir, M.B. (2017). A review on green synthesis of silver nanoparticles and their applications. Artificial Cells, Nanomedicine, and Biotechnology,
45(7), 1272-1291, DOl: https://doi.org/ 10.1080/21691401.2016.1241792.

Rahman, A., Kumar, S., Bafana, A., Lin, J., Dahoumane, S.A., \& Jeffryes, C. (2019). A mechanistic view of the light-induced synthesis of silver nanoparticles using extracellular polymeric substances of Chlamydomonas reinhardtii. Molecules, 24(19), 3506 DOI: https://doi.org/10.3390/molecules24193506

Redmond, P.L., Wu, X., \& Brus, L. (2007). Photovoltage and photocatalyzed growth in citrate-stabilized colloidal silver nanocrystals. The Journal of Physical Chemistry C, 111, 8942-8947. DOI: https://doi.org/10.1021/ ip0710436

Seifipour, R., Nozari, M. \& Pishkar, L. (2020). Green synthesis of silver nanoparticles using Tragopogon collinus leaf extract and study of their antibacterial effects. J Inorganic and Organometallic Polymers and Materials, 30, 2926-2936. DOI: https://doi.org/10.1007/ s10904-020-01441-9

Shah, A,, Lutfullah, G., Ahmad, K., Khalil, A.T., \& Maaza M. (2018). Daphne mucronatamediated phytosynthesis of silver nanoparticles and their novel biological applications, compatibility and toxicity studies. Green Chemistry Letters and Reviews, 11(3), 318333. DOI: https://doi.org/10.1080/ 17518253.2018 .1502365

Siddiqi, K.S., Husen, A., \& Rao, R.A.K. (2018). A review on biosynthesis of silver nanoparticles and their biocidal properties, Journal of Nanobiotechnology, 16, 148-156. DOI: https://doi.org/10.1186/s1 2951-018-0334-5

Singhal, A., Singhal, N., Bhattacharya, A., \& Gupta, A. (2017). Synthesis of silver nanoparticles (AgNPs) using Ficus retusa leaf extract for potential application as antibacterial and dye decolourising agents. Inorganic and NanoMetal Chemistry. 47(11), 1520-1529. DOI: https://doi.org/10.1080/24701556.2017.135 7604

Sood, R., \& Chopra, D.S. (2018) Metal-plant frameworks in nanotechnology: an overview. Phytomedicine, 50, 148-156. DOI: https://doi.org/10.1016/i.phymed.2017.08.025

Wybraniec, S., Starzak, K., Skopińska, A., Szaleniec, M., Słupski, J., Mitka, K., Kowalski, P. \& Michałowski, T. (2013). Effects of metal cations on betanin stability in aqueous-organic solutions. Food Science and Biotechnology, 22(2), 353-363. DOI: https://doi.org/ $10.1007 / \mathrm{s} 10068-013-0088-7$ 